\title{
ASSESSMENT OF PERSONAL FINANCE MANAGEMENT AMONG TRANSPORT LOGISTICS STUDENTS'
}

\author{
Jurgita Ginavičienè \\ Indrẻ Sprogytė \\ Juras Preikšaitis \\ Vilnius College of Technologies and Design, Lithuania
}

\begin{abstract}
The article presents the results of quantitative research carried out with 305 Vilnius Technologies and Design College transport logistics students in Lithuania. The research focused on the students' personal financial management. During 2016 the practical training they filled out an electronic demographic data form online and evaluated their personal financial management. The results revealed that transport logistic students assume personal responsibility for their personal financial management. They have short-term goals -at a profitable period to accumulate resources for periods when revenues are not sufficient. The maximum amounts of transport logistic students costs involved food, stationary expenses, presents, taxes.
\end{abstract}

Keywords: personal finance, personal finance management, student.

\section{Introduction}

It is important to analyse personal finances and management skills in the context of the scientific literature both for each person individually and the whole country.

It is essential to learn how to manage one's own personal finances during the years of studies, so that, after finding employment and receiving regular income, students would be able to skilfully handle larger amounts of money. Changing activities from studies to the working environment is a very risky time, because there is a great temptation to borrowing options. Having no life experience, students can easily assume long-term commitments for several years ahead. They do evaluate neither their possibilities nor the needs, and the fact is that these loans can become a serious obstacle to a successful career.

Various events take place in one's personal life. Financial occurrence probability - or an event can be predicted, or not. Some events are easily predictable, and other ones are hardly anticipated or are quite unpredictable. The 
coping techniques of such unexpected and unpredictable things need to be learnt to manage and plan personal finances (Valickas et al. 2015).

The aim of the paper is to explore the personal financial management of Vilnius Technology and Design College transport logistics students.

In order to achieve the objective, the following tasks have been put forward:

1. Evaluate the importance of personal financial management and benefits.

2. Present the main results of research on transport logistic students' personal finances and management skills.

Methods used in the paper: comparative analysis of the literature resources, questionnaires, empirical data grouping, comparison and analysis, the portrayal of the obtained results.

\section{The importance of personal financial management}

Personal finances are the whole complex, consisting of the income, expenses and free funds available to save or invest (Taujanskaite \& Jurevičienè, 2010). Personal finances and household decisions are an important part of the financial system, which the whole country's economic level depends on.

Personal finances cover all individual financial decisions and activities, such as insurance, savings, investment, mortgage, debt etc. (Barkauskaite \& Eglinskaitè, 2016.).

Personal financial management skills on the first independent life stages have a significant impact not only on the current economic prosperity, but also have a considerable influence on the future planning (Navickas, et al., 2014).

It is extremely important for the people to know how effectively personal finances can be managed, in order to ensure one's personal financial stability (Gedmintienè \& Visockaitè, 2016)

According to (Banionyte \& Dagilienè, 2011) the person, managing his/her finances, will use them rationally and will know how to avoid losses.

Therefore, a good knowledge of financial literacy makes it possible to take rational every-day decisions and helps to spend less money.

One of the most important tools in the management of personal finances is the budget management which requires efforts, time, and discipline and also provides a clear picture of where and in what quantities money is flowing. (Valickas et al., 2015).

Personal finance management is the distribution of income and expenditure cuts, which not only balances the personal income and expenditure of the budget, but also helps to increase the value of the assets managed (Barkauskaite \& Eglinskaitè, 2016.). 
Personal financial management is seen as a personal financial decision process and is linked only to a certain person (Jurevičienė \& Gausiené, 2010)

Young people often do not know or do not understand simple financial concepts and terms, do not identify them in their own environment, and are unable to apply them in practice. Hence, from a long term perspective it can be said that the poor financial sophistication can lead not only to poor personal financial management, but also affect the entire national system, as it is an integral part of the mechanism element (Navickas, et al., 2014).

\section{Personal financial management principles}

A person can achieve his/her targets only when he/she behaves consistently in compliance with his/her ideas, objectives. In fact, personal finance management is based on the same principles as the company's financial management (Jurevičienè \& Gausienè, 2010). It should follow two principles:

1. It is important to distinguish between the desires and real needs. As usual, increasing revenue increases desires, after satisfying one desire, its place is taken by another one.

2. Priority - retirement planning. Of course, different people's incomes and needs at different stages of life will not be the same, but one rule applies to all - an age pension, if the accumulation is not seen about in advance, income is certainly lower than the needs. Therefore pension planning should be the main goal and priority.

Obviously the two main principles show that the most important is needs and retirement planning which leads to personal financial success.

According to Mrs J. Varanauskienè (Andriukaitis et al., 2009), personal finance management principles are very simple: the expenses should not exceed the income (present and future); part of the revenues should be invested for a longer time; the person should insure himself/herself in case of financial problems; he/she should be aware not to plump into debt. If each of these principles are always applied, it is likely that financial difficulties would be faced extremely rarely.

One of the most important personal financial management principles is financial planning. A person must have a goal and a plan to assess all possible risks. (Barkauskaitė \& Eglinskaitė: in 2016.).

Financial planning is important to personal financial management (Gitman et al., 2013). It deals with future plans and objectives; to achieve the objectives, one should evaluate various measures to ensure the security of personal finance.

In order to ensure the personal financial stability, the person must have a goal and create a personalized plan to assess all possible risks. When planning personal finances, the current situation is assessed; the goals, the plan execution, 
monitoring and re-evaluation are set. If personal financial management is completed in this way, good results will be achieved (Banionyte \& Dagiliené, 2011).

An integral part of personal financial management area is saving, because every person, depending on his/her level of income, should set aside a certain portion of the funds on a monthly basis, thus forming a fund whose resources are targeted on unforeseen problems (Čečkauskaitė \& Kviklienè 2014).

Individuals need to evaluate not only their current financial situation, but also anticipate future needs and things that can happen in a week, in half a year, thus being ready in advance (Andriukaitis et al., 2009). This is one of the most important personal financial management principles (Barkauskaite \& Eglinskaitė: in 2016.).

Table 1 Grouping expenses (Ginavičienė et al., 2017)

\begin{tabular}{|c|c|c|}
\hline $\begin{array}{c}\text { Grouping expenses } \\
\text { according to } \\
\text { (Valickas et al., 2015). }\end{array}$ & $\begin{array}{l}\text { Grouping expenses } \\
\text { according to (Čečkauskaitè } \\
\text { \& Kviklienė, 2014) }\end{array}$ & $\begin{array}{l}\text { Grouping of the expenses } \\
\text { applied in the research }\end{array}$ \\
\hline \multirow[t]{2}{*}{ Food and beverages } & Catering (at home) & Food \\
\hline & $\begin{array}{l}\text { Catering (on weekdays at } \\
\text { college) }\end{array}$ & Beverages \\
\hline Clothes and footwear & Clothes and footwear & Clothes and footwear \\
\hline Premises & $\begin{array}{ll}\begin{array}{l}\text { Dwelling } \\
\text { (dormitory/rental) }\end{array} & \text { space } \\
\end{array}$ & Taxes on housing \\
\hline Transport & Transport & Transport \\
\hline Means of communication & Communication & \\
\hline Health care & $\begin{array}{l}\text { Medicine, vitamins, food } \\
\text { supplements }\end{array}$ & Medicine \\
\hline Beauty treatments & $\begin{array}{lll}\begin{array}{l}\text { Personal hygiene } \\
\text { cosmetics }\end{array} & \text { and } \\
\end{array}$ & Beauty treatments \\
\hline Education & $\begin{array}{l}\text { Study material, educational } \\
\text { literature, stationary }\end{array}$ & Stationary expenses \\
\hline Leisure & $\begin{array}{l}\text { Entertainment (cinema, } \\
\text { theatre, clubs) and healthy } \\
\text { lifestyle (gym) }\end{array}$ & Entertainment \\
\hline \multicolumn{3}{|l|}{ Insurance } \\
\hline $\begin{array}{l}\text { Additional expenses: } \\
\text { presents, jewellery, charity } \\
\text { and etc. }\end{array}$ & Pets & Present expenses \\
\hline $\begin{array}{l}\text { Other expenses: credit cards } \\
\text { service fees, legal services, } \\
\text { charity and etc. }\end{array}$ & Public utilities & Other expenses: taxes \\
\hline Children supervision & & \\
\hline
\end{tabular}


Effective personal finance management is calculating the income and expenses. To change something in one's behaviour, to acquire useful habits, the person first needs to define the situation (Valickas et al. 2015). Only after clearly identifying on what and how much money is spent and what revenue is generated, the person can start thinking about saving and efficient consumption strategies.

Personal financial management essence is the revenue and cost analysis. Regarding the analysis, the recorded numbers can be measured in terms of key criteria such as exactly how much money is spent and where, what the cost trends are and what the categories of expenses are. Table 1 shows the grouping of expenses, which were offered by the researchers.

Personal preferences are interpreted on the basis of financial considerations after purchasing financial products and releasing available funds (Jurevičienè \& Gausienè, 2010).

Financial motives, according to the economic theory, are cash reserves, precautions (caution), money savings for durable consumer goods and housing (Paas et al, 2007), asset management, covering investment and entrepreneurship.

\section{Study on personal finance management among transport logistics students}

The study took place in 2016 during the practical training of transport logistics students of Vilnius Technology and Design College. In order to investigate the transport logistics students' personal financial management and to assess whether they have a personal financial management knowledge needed, quantitative research using a questionnaire method was carried out. A questionnaire was prepared to make a quantitative study. The study findings were systematized and analysed via MS Excel. The analysis of the results used descriptive statistics (percentage distribution).

Study sample - survey sampling bias is calculated according to the Paniott formula (Valackienè, 2004)

$$
n=\frac{1}{\Delta^{2}+\frac{1}{N}} ;
$$

where: $\mathrm{n}$ - sample size,

$\Delta^{2}-$ bias probability,

$\mathrm{N}-$ target population, which ensures approximately a $5 \%$ probability of bias.

After the evaluation of the study sample bias, it was found that the minimum number of respondents was to be 242 students. The number of respondents was 305 students.

Data collection method - a questionnaire survey, which was carried out electronically, through www.apklausa.lt and sent to the students via their personal e-mails. 
The study was aimed to analyze the transport logistic students personal financial management and to assess whether they have a personal financial management knowledge needed.

The research was intended to identify not only the transport logistics students' sources of income and their size, but also to define the average monthly expenses and their structure, naming the key areas that receive the most students' funds.

Age group difference is important to personal financial management. There are 4 groups -single, a studying or recently employed person; married / married without children; married / married, having children; pre-retirement age. (Valickas et al. 2015).

Respondents in the study belong to the group who do not have a family, are a student or recently employed people.

The investigation showed that the majority of the respondents only studied (46.5 percent). Those working irregularly accounted for 32.6 percent. The respondents usually worked at weekends. 20.9 percent of the respondents managed to combine studies and work.

J. M Keynes (1936) developed a theory stating that consumption depends on the current level of income. According to this theory, the financial behaviour of individuals is determined only by income (Barkauskaite \& Eglinskaité, 2016).

The respondents were grouped according to income as follows:

- $\quad$ Less than EUR 230 a month, 44 percent.

- From EUR 230 to EUR 440 a month, 30 percent.

- $\quad$ More than EUR 440 a month, 26 percent.

Thus, according to the theory it was evaluated whether it was true that higher earners spent more income.

The survey results revealed that the transport logistic students, who were not regularly employed and received more income than studying ones, spent 13 percent more. Meanwhile, students combining studies and work spent 40 percent more than just studying ones.

An integral part of personal financial management areas is saving (Jurevičienė \& Gausienė, 2010, Andriukaitis et al., 2009, Čečkauskaite \& Kviklienè 2014, Barkauskaitė \& Eglinskaitè: in 2016, Murphy \&Yetmar, 2010), because everyone, depending on his/her level of income, should set aside a certain portion of the funds on a monthly basis, thus forming a fund, whose resources are for unforeseen problems.

During the personal financial management investigation carried out by the transport logistic students, it was found that only enrolled students usually did not save, students having irregular work were saving; such a fact was mentioned by 30 percent of the respondents. Comparing only studying students and those who 
combined work and studies showed that the working students constantly saved, and it was mentioned by as many as 70 percent of the students participating in the research.

Summing up, it should be noted that the transport logistic students who were aware of their financial situation and got a higher month-income were likely to save. They sought not to accumulate a larger amount of money for their retirement, but to accumulate reserves when revenues would not be sufficient.

During the research there were analysed the costs and there was determined the average monthly expenditure, and they were grouped as follows:

- $\quad$ Less than EUR 230 a month, spent by 51 percent.

- $\quad$ From EUR 230 to EUR 440 a month, spent by 32 percent.

- More than EUR 440 a month, spent by 15 percent.

The results are logical and reasonable, taking into account the distribution of the respondents, the most income and expenses were generated by the group of respondents whose amount of money was less than EUR 230.

Personal financial management essence is the revenue and cost analysis. Regarding the analysis (Valickas et al., 2015) (Čečkauskaitė \& Kviklienè 2014), the recorded numbers can be measured in terms of key criteria such as exactly how much money is spent and where, what the cost trends are and what the categories of expenses are.

Thus, according to the theory, table 1, grouping of expenses the evaluation of scientific findings: the table shows the expense areas according to which the respondents were given the grouping of the expenses. The distribution is presented in Figure 1.

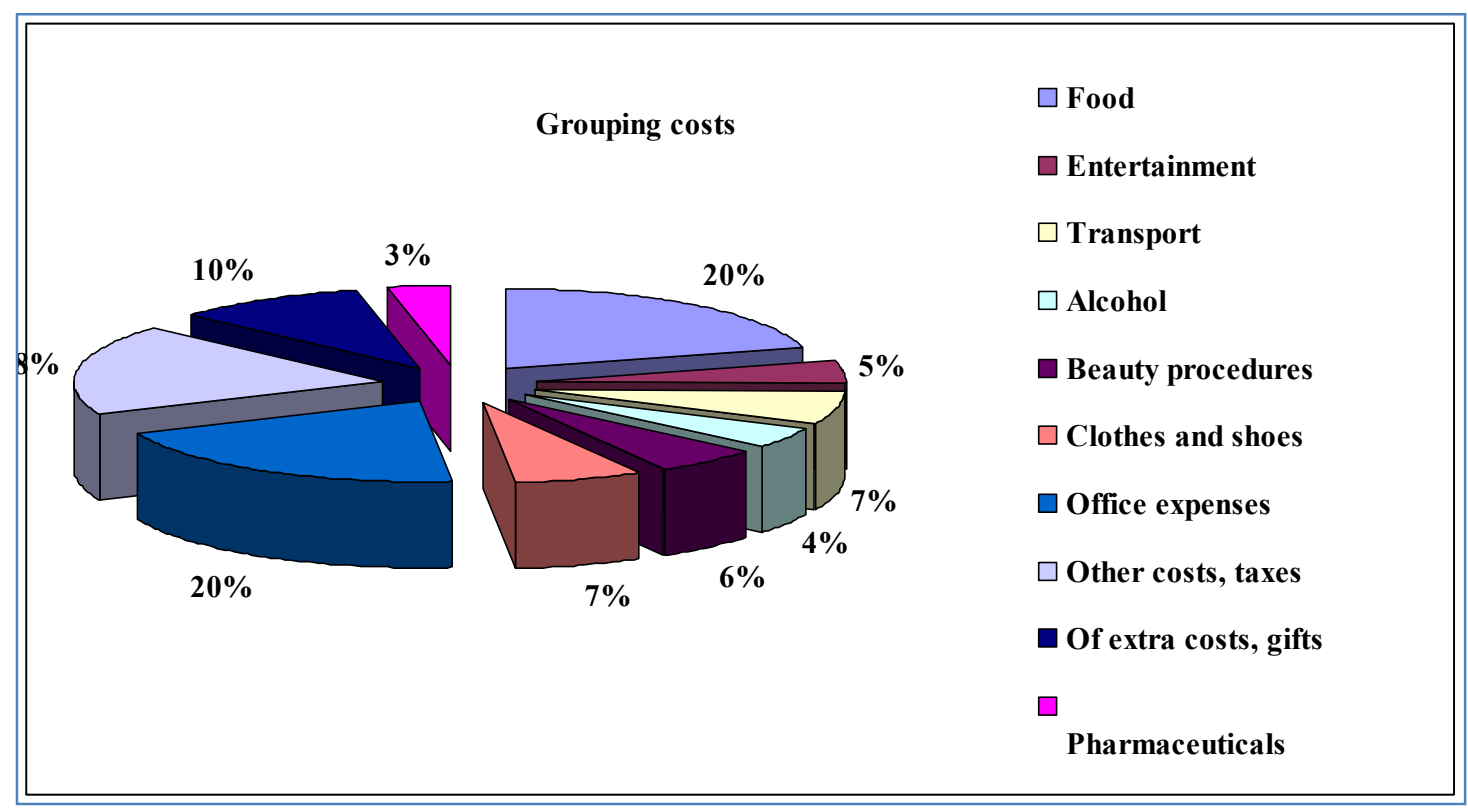

Figure 1 Transport logistics students' costs grouping (Ginavičienė et al., 2017) 
The maximum amount of the Transport logistic students' expenses was on food, stationary expenses, presents, taxes.

The respondents indicated the amount of food and stationary expenses, which included a tuition fee paid by the most of them, -20 percent.

Taxation - this was money spent on housing (dormitory / rent); 18 percent.

Clothing, footwear; 7 percent.

Beauty treatments; 6 percent.

Transport (public transport in the city, hiring a taxi, visiting parents, living in other cities, and etc.); 7 percent.

Entertainment; 5 percent.

Medicinal products; 3 percent.

Financial planning is important to personal financial management (Gitman et al., 2013, ) A person must have a goal and a plan to assess all possible risks. (Barkauskaite \& Eglinskaite: in 2016.).

The analysis of the results showed that the students having a regular saving plan made up 55 percent, students saving irregularly made up 20 percent, 25 percent of the students did not save. Since more than half of the respondents mentioned that they had a saving plan, they were asked to indicate the amounts which they managed to put aside every month:

- $\quad$ EUR 10 to 20 - 18 percent of the students.

- $\quad$ EUR 20 to $50-21$ percent of the students.

- $\quad$ EUR 50 to 100 - 16 percent of the students.

Summing up, it can be said that Transport logistics students know what personal finance management is and how it is important in their lives.

Like the majority of Lithuanian residents, transport logistic students seek not a basic personal finance management goal - to accumulate as much money as possible for retirement, but they have short-term goals -at a profitable period to accumulate resources for periods when revenues are not sufficient.

According to the survey, it can be stated that in Lithuania there is a positive trend in the personal finance management sphere, transport logistic students assume personal responsibility for their financial situation.

\section{Conclusions}

Personal financial management is important and useful because it allows protecting the personal financial stability, planning and rationally using incomes, expenses, and anticipating the risks and avoiding them. Personal finance management utility gets forecasting and providing basic financial considerations, analysing the current financial situation and cost savings. 
In order to investigate the transport logistics students' personal finance management a quantitative study was carried out. The respondents, taking part in the study, belonged to a group which did not have a family, they were students or recently employed ones. During the investigation into personal financial management among transport logistic students, those students who were aware of their financial situation and got a higher month-income were likely to save. The maximum amounts of transport logistic student costs involved food, stationary expenses, presents, taxes. According to the survey, it can be stated that transport logistic students assume personal responsibility for their personal financial management.

\section{References}

Andriukaitis, D., Čeponytė, Z., Jurevičienè, D., Kriščiukaitytè, K., Vaičiulis, M., Vaitkunskienè, R., Varanauskienè, J. (2009). Finansiniu paslaugu vadovas. Vilnius: Lietuvos vartotojų institutas.

Banionytè, D., Dagilienè, L. (2011). Asmeniniai finansai ir finansų planavimas (pp. 10-12). Ekonomika ir vadyba 2011. Kaunas: Technologija.

Barkauskaitè, A., Eglinskaitè, V. (2016). Problems of personal financial safety assurance (pp. 63-69). 12th International Prof. V. Gronskas Scientific Conference Economy Development: Theory and Practise. Vilnius University Kaunas Faculty of Humanities. Downloaded from http://www.knf.vu.lt/dokumentai/failai/konferenciju/gronsko2016/GRONSKO_KONFE RENCIJOS_LEIDINYS_2015.pdf

Čečkauskaite, S., Kviklienè, D. (2014). Studentų asmeniniu finansų ir jų valdymo igūdžiu vertinimas (pp. 119-127). 11-oji Prof. Vlado Gronskio mokslinį magistrantų ir doktorantu konferencija Ūkio pletra: teorija ir praktika. Kaunas. Downloaded from http://www.knf.vu.lt/dokumentai/failai/konferenciju/gronsko2016/VUKHF_Gronsko_le idinys_2014.pdf

Gedmintiene Deimantaite, D., Visockaitè, A. (2016). The importance of personal finance for investment and applying financial behavior principles in personal finance investment decisions in Lithuania (pp. 118-131). Societal Studies, v. VIII, n. 1. Vilnius: Mykolas Romeris University. DOI:10.13165/SMS-16-8-1-7

Gitman, L. J., Joehnk, M. D., Billingsley, R. S. (2014). Personal Financial Planing. SouthWestern, Cengage Learning.

Jurevičienè, D., Gausienè, E. (2010). Finansinès gyventojų elgsenos ypatumai (pp. 222-237). Business: theory and practice. v. XI, n. 3. DOI:10.3846/btp.2010.25

Murphy, D. S., Yetmar, S. (2010). Personal financial planning attitudes: a preliminary study of graduate students (pp.811-817). Management Research Review, v. XXXIII, n. 8. Downloaded from http://www.emeraldinsight.com/doi/pdfplus/10.1108/01409171011065617

Navickas, M., Gudaitis, T., Krajnakova, E. (2014) Influence of financial literacy on management of personal finances in a young household (pp. 32-40). Business: theory and practice. v. $X V, n$. 1. Downloaded from http://dx.doi.org/10.3846/btp.2014.04 
Jurgita Ginavičiene, Indrè Sprogytè, Juras Preikšaitis. Assessment of Personal Finance

Management Among Transport Logistics Students'assessment of Personal Finance

Management Among Transport Logistics Students'

Paas, L. J., Bijmolt, T. H. A., Vermunt, J. K. (2007). Acquisition patterns of financial products: a longitudinal investigation (pp.229-241). Journal of Economic Psychology v. XXVIII, $n$. 2. DOI:10.1016/j.joep.2006.06.006

Taujanskaite, K., Jurevičienė, D. (2010). Asmeninių finansų valdymo ypatumai ekonominio nestabilumo sąlygomis (pp.104-111). Business in XXI century. v. II, n. 2. Downloaded from http://www.mla.vgtu.lt/index.php/mla/article/viewFile/mla.2010.042/95

Valackienè, A. (2004). Sociologinis tyrimas:vadovèlis. Kaunas :Technologija

Valickas, A., Chomentauskas, G., Dereškevičiūtè, E., Žukauskaitė, I., Navickienė, L. (2015). Asmeninès karjeros valdymas studentui. Vilnius:Vilniaus universitetas. 